\title{
PENINGKATAN AKTIVITAS DAN HASIL BELAJAR MATEMATIKA TENTANG KPK DENGAN MODEL PEMBELAJARAN CARD SORT BERBANTU MEDIA KARTU BILANGAN
}

\section{Sutopo $^{\bowtie}$}

SD 1 Payaman Mejobo Kudus

\section{Info Artikel Abstract}

Sejarah Artikel:

Diterima 1 Okt 2019

Direvisi 1 Nov 2019

Disetujui 6 Nov 2019

\section{Keywords:}

Card Sort, Card

Number, Activities And

Learning Outcomes

Paper type:

Research paper
This study aims to improve the activities and learning outcomes of Mathematics about KPK with a card sort learning model assisted by number card media for fifth grade students at Payaman 1, Mejobo Kudus Semester 1 2018/2019 Academic Year. This research is a class action research. The subjects were students in grade V Payaman 1 elementary school, Mejobo Kudus Semester 1 2018/2019 Academic Year, amounting to 27 students consisting of 9 men and 18 women. The study consisted of two siklu, and each was conducted in two meetings. Data collection techniques are done by tests, field notes. Research instruments using tests and observation alloys. Analysis of the data used in this research is comparative descriptive. The results showed based on a series of actions in the first cycle and second cycle with the application of a card sort learning model assisted by number card media can increase: (1) Student learning activities. The results showed student learning activities increased by 12 points from initial conditions 65 and final conditions 77; (2) The results of the study showed the learning outcomes shown by the average student increased by 16 points, from the initial condition of 65 and the final condition reached 81.

\begin{abstract}
Abstrak
Penelitian ini bertujuan untuk meningkatkan aktivitas dan hasil belajar Matematika tentang KPK dengan model pembelajaran card sort berbantu media kartu bilangan bagi siswa kelas V SD 1 Payaman, Mejobo Kudus Semester 1 Tahun Pelajaran 2018/2019. Penelitian ini merupakan penelitian tindakan kelas. Subjeknya adalah siswa kelas V SD 1 Payaman, Mejobo Kudus Semester 1 Tahun Pelajaran 2018/2019 yang berjumlah 27 siswa yang terdiri dari laki-laki 9 dan perempuan 18. Penelitian terdiri dari dua siklu, dan masing-masing dilakukan dalam dua kali pertemuan. Teknik pengumpulan data dilakukan dengan tes, catatan lapangan. Instrumen penelitian menggunakan tes dan paduan observasi. Analisis data yang digunakan dalam penelitian ini adalah deskriptif komparatif. Hasil penelitian menunjukkan berrdasarkan serangkaian tindakan pada siklus I dan siklus II dengan penerapan model pembelajaran card sort berbantu media kartu bilangan dapat meningkatkan: (1) Aktivitas belajar siswa. Hasil penelitian menunjukkan aktivitas belajar siswa meningkat 12 poin dari kondisi awal 65 dankondisi akhir 77; (2) Hasil penelitian menunjukkan hasil belajar yang ditunjukkan dengan rata-rata siswa meningkat 16 poin, dari kondisi awal 65 dan kondisi akhir mencapai 81 .
\end{abstract}

(C) 2019 Universitas Muria Kudus

\footnotetext{
Alamat korespondensi:

Program Studi Pendidikan Matematika

Fakultas Keguruan dan Ilmu Pendidikan Universitas Muria Kudus

Kampus UMK Gondangmanis, Bae Kudus Gd. L. 1t I PO. BOX 53 Kudus

Tlp (0291) 438229 ex.147 Fax. (0291) 437198

E-mail: sutoposd42@gmail.com
}

p-ISSN 2615-4196

e-ISSN 2615-4072 


\section{PENDAHULUAN}

Matematika sebagai suatu mata pelajaran di sekolah dinilai cukup memegang peran penting, karena metematika merupakan suatu sarana berpikir untuk mengkaji sesuatu secara logis dan sistematis. Oleh sebab itu, matematika sangat penting untuk dikuasai sedini mungkin oleh para siswa. Namun pada kenyataannya, banyak orang yang tidak menguasai matematika.Termasuk anakanak yang masih duduk di bangku SD/MI. Mereka menganggap bahwa matematika sulit dipelajari, guru matematika dianggap tidak menyenangkan, membosankan, menakutkan, angker, killer, dan sebagainya.

Anggapan ini menyebabkan mereka semakin takut dan enggan untuk belajar matematika. Akibatkan hasil belajar matematika mereka menjadi rendah. Selain itu mereka menjadi semakin tidak suka terhadap pelajran matematika. Sehingga hasil belajarnya pun semakin merosot. Di sisi lain peningkatan aktivitas dan hasil belajar siswa merupakan tujuan yang diikuti dalam upaya peningkatan kualitas pembelajaran.

Keaktifan siswa selama proses belajar mengajar merupakan salah satu indikator adanya keinginan atau motivasi siswa untuk belajar (Anitah, 2009:2.13). Siswa dikatakan memiliki keaktifan apabila ditemukan ciri-ciri perilaku seperti sering bertanya kepada guru atau siswa lain, mau mengerjakan tugas yang diberikan guru, mampu menjawab pertanyaan, senang diberi tugas belajar dan sebagainya. Prinsip-prinsip mengaktifkan siswa menurut yaitu (Uzer, 2013:88): (1) prisnsip motivasi, (2) prinsip latar atau konteks, (3) prinsip fokus (pemusatan perhatian), (4) prinsip sosialisasi, (5) prinsip belajar sambil bekerja, (6) prinsip individualisasi, (7) prinsip menemukan, (8) prinsip pemecahan masalah.

Sedangkan Hasil belajar yang utama adalah pola tingkah laku yang bulat (Hamalik, 2010:30). Bukti bahwa seseorang telah belajar ialah terjadinya perubahan tingkah laku pada orang tersebut. Hasil belajar secara lebih ringkasnya adalah mencakup tiga aspek yaitu kognitif, afektif, dan psikomotorik. Hal ini sesuai dengan yang disampaikan oleh Bloom bahwa tiga taksonomi yang disebut sebagai ranah belajar, yaitu (Rifa" $\mathrm{i}$, 2010:86): (1) ranah kognitif, ranah afektif, dan ranah psikomotorik. ranah kognitif berkaitan dengan hasil berupa pengetahuan, kemampuan dan kemahiran intelektual, (2) ranah afektif berkaitan dengan perasaan, sikap, minat, dan nilai, (3) ranah psikomotorik berkaitan dengan kemampuan fisik seperti kemampuan motorik dan syaraf, manipulasi objek, dan koordinasi syaraf.
Pada pembelajaran matematika tentang KPK, misalnya, hasil belajar siswa cukup rendah. Hal ini ditunjukkan dengan rata-rata kelas hanya mencapai 65 di bawah KKM Matematika, yakni 70. Untuk mengatasi masalah tersebut perlu dilakukan perbaikan agar memudahkan siswa belajar dan melaksanakan tanggung jawab individunya sebagai anggota kelompok dan mengurangi kebosanan atau kejenuhan jika guru mengelompokkan siswa secara permanen. Selain itu juga mengarahkan kegiatan siswa yang dimulai dengan mencari dan menemukan isi materi pembelajaran dengan menerapkan model pembelajaran yang sesuai dan menarik, guru akan mampu mendorong siswa terlibat secara aktif sehingga pada akhirnya mempengaruhi hasil belajar siswa. Peneliti menetapkan alternatif tindakan dengan menerapkan model pembelajaran card sort.

Model pembelajaran card sort ini guru menggunakan media kartu yang berisi informasi. Kartu dibagikan kepada siswa yang berupa potongan-potongan kertas, kemudian siswa melakukan usaha untuk menemukan kartu berkategori sama. Kegiatan card sorting akan menjadikan gerakan fisik yang dominan dalam hal ini dapat membantu mendinamiskan kelas yang jenuh atau bosan. Model pembelajaran card sort merupakan model yang dapat menumbuhkan keaktifan siswa dalam pembelajaran, membantu siswa dalam memahami pelajaran, serta diharapkan dapat tercapai hasil belajar yang baik, sebab, dalam penerapan model pembelajaran card sort guru menggunakan media kartu yang berisi informasi materi pelajaran dan informasi tersebut berisi beberapa kategori.

Model pembelajaran card sort (memilah dan memilih kartu) adalah kegiatan kolaboratif yang bisa digunakan untuk mengajarkan konsep, penggolongan sifat, fakta tentang suatu objek atau mengulangi informasi (Silberman, 2013:171). Model pembelajaran card sort mempunyai langkah-langkah dalam melaksanakan metode ini. Langkah-langkah model pembelajaran card sort adalah sebagai berikut (Zaini, 2008:50): (1) setiap siswa diberikan potongan kertas yang berisi informasi atau contoh yang tercakup dalam satu atau lebih kategori, (2) setiap siswa berkeliling mencari kategori di dalam kelas untuk menemukan kartu dengan kategori yang sama (guru dapat mengumumkan atau membiarkan siswa menemukannya sendiri), (3) siswa dengan kategori yang sama diminta mempresentasikan kategori masing-masing di depan kelas, (4) seiring dengan presentasi dari tiap-tiap kategori tersebut, guru 
memberikan poin-poin penting terkait materi pelajaran.

Model pembelajaran card sort juga memberi kesempatan kepada siswa untuk memperoleh pengalaman, praktis, dan konkret dengan cara melakukan kegiatan mengumpulkan informasi menggunakan media kartu-kartu tersebut. Hal tersebut sesuai dengan karakteristik siswa SD yang berada dalam tahap perkembangan operasional konkret, pada tahap ini siswa belum mampu memahami konsep-konsep yang bersifat abstrak. Maka dari itu dalam pembelajaran, guru berusaha agar siswa lebih mudah menerima dan memahami materi pelajaran yang berisi konsepkonsep yang abstrak.

Penggunaan media pembelajaran ini diharapkan dapat memudahkan siswa dalam memahami materi yang disampaikan dan membantu meningkatkan motivasi, aktivitas, dan hasil belajar siswa. Motivasi, aktivitas, dan hasil belajar siswa merupakan satu kesatuan yang saling mempengaruhi dan tidak terpisahkan. Motivasi siswa akan mempengaruhi aktivitas yang dilakukan. Penggunaan kartu bilangan sebagai media pembelajaran dalam penelitian ini bertujuan untuk meningkatkan motivasi, aktivitas, dan hasil belajar siswa tersebut. Kartu bilangan sesuai untuk siswa sekolah dasar, karena dalam penggunaannya kartu bilangan disesuaikan dengan karakteristik materi. Dari uraian permasalahan di atas, maka penulis tertarik melakukan penelitian tindakan kelas melalui model pembelajaran card sort yang berbantu media kartu bilangan dengan tujuan untuk meningkatkan keaktifan dan hasil belajar siswa.

Sementara tujuan penelitian ini sendiri untuk: (1) Peningkatan aktivitas belajar Matematika tentang KPK melalui model pembelajaran card sort berbantu media kartu bilangan, (2) Peningkatan hasil belajar Matematika tentang KPK bagi siswa kelas V SD 1 Payaman Kecamatan Mejobo Kabupaten Kudus Semester I Tahun Pelajaran 2018/2019 setelah dibelajarkan dengan model pembelajaran card sort berbantu media kartu bilangan. Manfaat penelitian tindakan kelas ini adalah dapat meningkatnya aktivitas belajar Matematika tentang KPK, dapat meningkatnya hasil belajar Matematika, dan hasil penelitian ini dapat menambah dan melengkapi hasil-hasil penelitian yang telah dilakukan guruguru lain.

\section{METODOLOGI PENELITIAN}

Penelitian dilakukan pada bulan Agustus 2018 sampai Desember 2018. Penyusunan jurnal refleksi pembelajaran dan proposal dilakukan pada bulan Agustus 2018 penyusunan RPP siklus I dan perangkatnya, pelaksanaan siklus I, analisis pelaksanaan siklus I dilakukan pada bulan September 2018, penyusunan RPP siklus II dan perangkatnya, pelaksanaan siklus II, analisis pelaksanaan siklus II dilakukan pada bulan September dan Oktober 2018, sedangkan penyusunan laporan penelitian dilakukan pada bulan Oktober 2018 sampai dengan Desember 2018.

Subjek Penelitian Tindakan Kelas ini adalah siswa kelas V Semester 1 SD 1 Payaman Kecamatan Mejobo Kabupaten Kudus tahun pelajaran 2018/2019 dengan jumlah siswa 27 terdiri dari 9 siswa putra dan 18 siswa putri. Siswa kelas V Semester 1 SD 1 Payaman Kecamatan Mejobo Kabupaten Kudus tahun pelajaran 2018/2019 memiliki karakterstik sangat beragam. Objek penelitian ini adalah adalah mata Pelajaran Matematika tentang KPK. Materi ini adalah materi matematika semester 1. Variabel yang diteliti sebagai tindakan adalah pemanfaatan model pembelajaran card sort berbantu media kartu bilangan serta sebagai hasil yang dicapai aktivitas belajar dan hasil belajar.

Metode Penelitian Tindakan Kelas digunakan dalam penelitian ini yang terdiri dari 2 siklus. Dalam setiap siklus tindakan saling berkaitan. Pada siklus 1 pembelajaran dilakukan dengan menggunakan model pembelajaran card sort berbantu media kartu bilangan, pada siklus 2 masih menggunakan model pembelajaran card sort berbantu media kartu bilangan Siklus 1 dan 2 berlangsung pada 4 pertemuan. Tahapan-tahapan dalam tiap siklus terdiri atas (1) membuat perencanaan tindakan (perencanaan), (2) melaksanakan tindakan sesuai yang direncanakan (pelaksanaan), (3) melaksanakan pengamatan terhadap tindakan yang dilaksanakan (pengamatan), (4) menganalisis dengan deskriptif komparatif dilanjutkan dengan refleksi terhadap hasil pengamatan tindakan (refleksi).

Data yang diambil dalam penelian ini adalah data kuantitatif dan kualitatif. Data kualitatif adalah data aktivitas belajar siswa. Data kuantitatif adalah hasil belajar Matematika tentang KPK. Data kualitatif terdiri dari yaitu: (1) Jurnal refleksi, dan (2) Aktivitas belajar. Dan data kuantitatif yaitu Hasil belajar Matematika tentang KPK. Teknik pengumpulan data: (1) Teknik dokumentasi berupa jurnal refleksi pembelajaran digunakan untuk mencari data kondisi awal aktivitas belajar dan hasil belajar siswa. Dokumentasi aktivitas belajar dapat dilihat jurnal mengajar guru, (2) Teknik pengamatan atau observasi digunakan untuk memperoleh data 
aktivitas belajar siswa pada siklus 1 dan 2 . Pengamatan dan observasi dilakukan oleh teman sejawat selaku kolaborator yang bertugas mengamati aktivitas guru dan siswa dengan memberikan check list pada lembar observasi, (3) Teknik tes tertulis digunakan untuk memperoleh data hasil belajar siswa pada siklus 1 dan 2 yang dilaksanakan pada tiap akhir siklus.

Alat pengumpulan data: (1) Dokumen daftar nilai untuk data hasil belajar Matematika tentang KPK dari siswa pada kondisi awal, (2) Dokumen catatan personal siswa dan jurnal mengajar guru untuk data aktivitas belajar siswa kondisi awal, (3) Lembar observasi/pengamatan untuk mencari data aktivitas belajar siswa pada siklus 1, (4) Butir soal tes tertulis untuk hasil belajar siswa pada siklus 1, (5) Lembar observasi/pengamatan untuk mencari data aktivitas belajar siswa pada siklus 2, (6) Butir soal tes tertulis untuk hasil belajar siswa pada siklus 2 .

Analisis data: (1) Teknik kualitatif. Teknik yang digunakan untuk menganalisis aktivitas belajar siswa dan guru. Terdapat 3 data aktivitas belajar yaitu data aktivitas belajar pada kondisi awal, data aktivitas belajar pada siklus 1 dan data aktivitas belajar pada siklus 2 dianalisis menggunakan teknik deskriptif komparatif dilanjutkan dengan refleksi. Deskriptif komparatif yaitu dengan membandingkan data aktivitas belajar kondisi awal dengan data aktivitas belajar siklus 1, membandingkan data aktivitas belajar siklus 1 dengan data aktivitas belajar siklus 2 dan membandingkan data aktivitas belajar kondisi awal dengan data aktivitas belajar kondisi akhir. Refleksi yaitu membuat simpulan berdasarkan deskriptif komparatif kemudian memberi ulasan atas simpulan tersebut untuk menentukan perlu tidaknya siklus berikutnya, (2) Teknik kuantitatif. Teknik yang digunakan untuk menganalisis data hasil belajar siswa. Terdapat 3 data hasil belajar siswa, yaitu data hasil belajar pada kondisi awal, siklus 1 dan siklus 2 dianalisis menggunakan teknik deskriptif komparatif dilanjutkan dengan refleksi. Deskriptif komparatif yaitu dengan membandingkan data hasil belajar kondisi awal dengan data hasil belajar siklus 1 , membandingkan data hasil belajar siklus1dengan data hasil belajar siklus 2 dan membandingkan data hasil belajar kondisi awal dengan data hasil belajar kondisi akhir. Refleksi, yaitu membuat simpulan berdasarkan deskriptif komparatif kemudian memberi ulasan atas simpulan tersebut untuk menentukan perlu tidaknya siklus berikutnya.

Indikator kinerja dalam penelitian ini dilihat dari peningkatan aktivitas dan hasil belajar Matematika tentang luas bangun datar siswa, dan indikator keberhasilan ditunjukkan dengan: (1) Perolehan rata-rata nilai aktivitas belajar $\geq 75$, (2) Perolehan nilai rata-rata hasil belajar $\geq 70$.

\section{HASIL DAN PEMBAHASAN}

Penelitian dilakukan pada bulan Agustus 2018 sampai Desember 2018. Subjek Penelitian Tindakan Kelas ini adalah siswa kelas V Semester 1 SD 1 Payaman Kecamatan Mejobo Kabupaten Kudus tahun pelajaran 2018/2019 dengan jumlah siswa 27 terdiri dari 9 siswa putra dan 18 siswa putri. Siswa kelas V Semester 1 SD 1 Payaman Kecamatan Mejobo Kabupaten Kudus tahun pelajaran 2018/2019 memiliki karakterstik sangat beragam. Objek penelitian ini adalah mata Pelajaran Matematika tentang KPK. Materi ini adalah materi matematika semester 1 .

\footnotetext{
Aktivitas Belajar siswa

Keaktifan siswa selama proses belajar mengajar merupakan salah satu indikator adanya keinginan atau motivasi siswa untuk belajar (Anitah, 2009:2.13).
} 


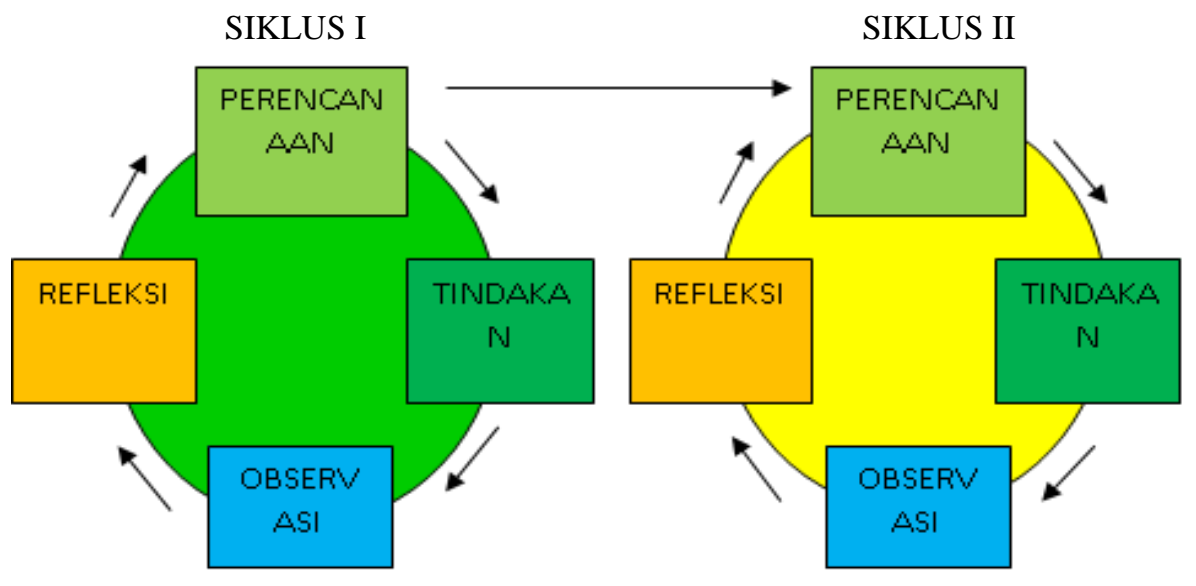

Gambar 1. Pelaksanaan Tindakan

Keaktifan siswa tercermin dalam aktivitas belajar siswa. Demikian peneliti sajikan aktivitas belajar kondisi awal kondisi akhir.

Tabel 1. Perbandingan Aktivitas Belajar Kondisi Awal, Kondisi Akhir

\begin{tabular}{ccc}
\hline Uraian & Kondisi Awal & $\begin{array}{c}\text { Kondisi } \\
\text { Akhir }\end{array}$ \\
\hline $\begin{array}{c}\text { Aktivitas } \\
\text { Siswa }\end{array}$ & 65 & 77
\end{tabular}

Terjadi perbandingan antara aktivitas belajar kondisi awal dan akhir akhir terlihat pada gambar 2.

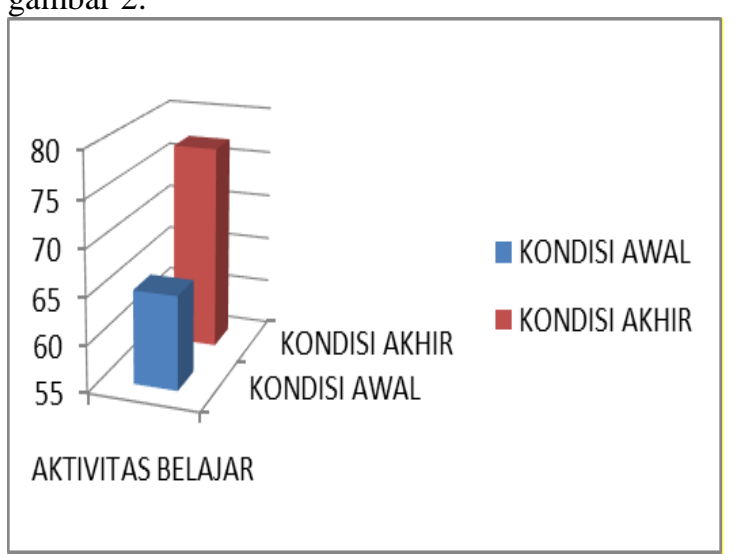

Gambar 2. Perbandingan Aktivitas Belajar

Kondisi Awal, Kondisi Akhir

Terjadi peningkatan aktivitas belajar sebesar 12 pada kondisi awal 65 dan kondisi akhir menjadi 77. Dari data di atas dapat dijelaskan bahwa aktivitas belajar siswa meningkat dan sesuai target penelitian, hal ini disebabkan penerapan model pembelajaran card sort berbantu media kartu bilangan.
Aktivitas belajar yang rendah pada kondisi awal dicarikan solusi dengan menerapkan model pembelajaran card sort berbantu media kartu bilangan.

Langkah-langkah pembelajaran yang peneliti gunakan untuk meningkatkan aktivitas belajar pada pembelajaran matematika tentang KPK bagi siswa kelas V SD 1 Payaman Kecamatan Mejobo Kabupaten Kudus Semester I Tahun Pelajaran 2018/2019 dengan model pembelajaran card sort berbantu media kartu bilangan secara garis besar sesuai dengan langkah siklus I dan 2 berikut:

Setiap siswa diberikan potongan kertas yang berisi kelipatan suatu bilangan informasi atau contoh yang tercakup dalam satu atau lebih kategori. Setiap siswa berkeliling mencari kategori KPK dua bilangan yang ditanyakan guru di dalam kelas untuk menemukan kartu dengan kategori yang sama (guru dapat mengumumkan atau membiarkan siswa menemukannya sendiri). Siswa dengan kategori yang sama yaitu yang memegang kartu KPK dan kelipatan suatu bilangan dari kartu tersebut diminta mempresentasikan kategori masing-masing di depan kelas. Seiring dengan presentasi dari tiap-tiap kategori tersebut, guru memberikan poin-poin penting terkait materi pelajaran tentang KPK 2 bilangan.

Setelah penerapan model pembelajaran card sort berbantu media kartu bilangan pada siklus I dan II, terjadi peningkatan aktivitas belajar sebesar 4 pada siklus I mencapai 73 dan siklus II menjadi 77. Sehingga jika diuraikan terjadi peningkatan sebesar 12 pada kondisi awal sampai dengan kondisi akhir penelitian, aktivitas belajar kondisi awal mencapai 65 dan kondisi akhir menjadi 77. 


\section{Hasil Belajar Siswa}

Hasil belajar yang utama adalah pola tingkah laku yang bulat (Hamalik, 2010:30). Bukti bahwa seseorang telah belajar ialah terjadinya perubahan tingkah laku pada orang tersebut. Hasil belajar secara lebih ringkasnya adalah mencakup tiga aspek yaitu kognitif, afektif, dan psikomotorik. Dibawah ini akan peneliti tampilkan tabel dan grafik perbandingan perolehan kondisi awal dengan kondisi akhir.

Tabel 2. Perbandingan Hasil Belajar Kondisi Awal, Akhir

\begin{tabular}{ccc}
\hline Indikator & Kondisi Awal & $\begin{array}{c}\text { Kondisi } \\
\text { Akhir }\end{array}$ \\
\hline Rata-rata & 65 & 81 \\
Nilai & 80 & 100 \\
Tertinggi & & \\
Nilai & 60 & 60 \\
Terendah & &
\end{tabular}

Perbandingan antara hasil belajar kondisi awal dan akhir akhir terlihat pada gambar 3 .

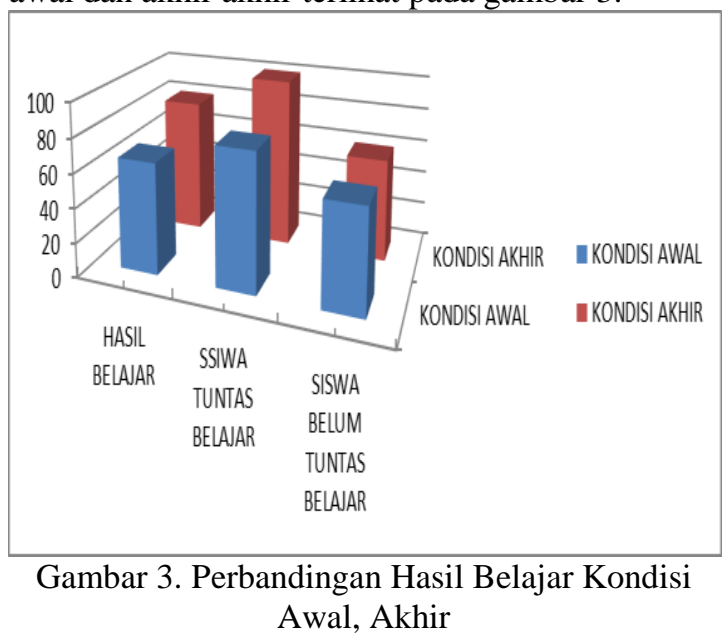

Jika di uraikan terjadi peningkatan pada kondisi awal dengan kondisi akhir sebagai berikut: (1) Hasil belajar yang ditunjukkan dengan rata-rata siswa meningkat 16 poin dari kondisi awal 65 , kondisi akhir mencapai 81, (2) Nilai tertinggi meningkat 20 poin perolehan pada dari kondisi awal 80, kondisi akhir mencapai nilai tertinggi 100, (3) Nilai terendah tetap perolehan pada dari kondisi akhir 60 maupun kondisi akhir 60 .

Setelah pelaksanaan pembelajaran dengan penerapan model pembelajaran card sort berbantu media kartu bilangan pada pertemuan kedua siklus I dan siklus II peneliti melakukan penilaian dengan melaksanakan tes formatif. Peneliti menyusun soal tes formatif sesuai dengan tujuan pembelajaran yang ingin dicapai. Hasilnya terjadi peningkatan hasil belajar sebesar 16 pada kondisi awal rata-rata siswa 65 dan kondisi akhir menjadi 81.

Hal ini sesuai dengan pendapat Zaini (2008:51) model pembelajaran card sort mempunyai kelebihan: (1) lebih mudah menangkap materi, (2) siswa lebih antusias dalam pembelajaran, (3) sosialisasi antar siswa lebih terbangun, (4) meringankan beban kerja guru di kelas. Hal ini juga sesuai dengan pendapat Arsyad (2011:21) manfaat media pembelajaran, sebagai berikut: (1) penyampaian pelajaran menjadi lebih baku, (2) proses pembelajaran bisa lebih menarik, (3) proses pembelajaran menjadi lebih interaktif, (4) efisiensi dalam waktu, (5) meningkatkan kualitas hasil belajar siswa, (6) media memungkinkan pembelajaran dapat disajikan di mana dan kapan saja sesuai dengan yang diinginkan, (7) media dapat menumbuhkan sikap positif siswa terhadap materi dan proses belajar, (8) mengubah peran guru ke arah yang lebih positif dan produktif.

\section{SIMPULAN}

Berdasarkan serangkaian tindakan pada siklus I dan siklus II dengan penerapan model pembelajaran card sort berbantu media kartu bilangan dapat meningkatkan: (1) Aktivitas belajar siswa. Hasil penelitian menunjukkan aktivitas belajar siswa meningkat 12 poin dari kondisi awal 65, kondisi akhir 77, (2) Hasil belajar siswa. Hasil penelitian menunjukkan hasil belajar yang ditunjukkan dengan rata-rata siswa meningkat 16 poin dari kondisi awal 65 , kondisi akhir mencapai 81.

Berdasarkan hasil penelitian maka disarankan kepada para guru untuk: (1) lebih sering melatih siswa dengan berbagai metode/model pembelajaran, walaupun pada taraf yang sederhana, (2) meningkatkan keterampilan dalam mengelola pembelajaran dengan menerapkan berbagai metode/model pembelajaran yang aktif dan interaktif, (3) menerapkan model pembelajaran card sort berbantu media kartu bilangan dalam pembelajaran Matematika.

\section{UCAPAN TERIMAKASIH}

Penulis mengucapkan terimakasih kepada kepala SD 1 Payaman Kabupaten Kudus yang telah memberikan ijin untuk melaksanakan kegiatan penelitian. Selain itu, peneliti juga mengucapkan terimaksih kepada siswa kelas V di SD 1 Payaman Kabupaten Kudus yang telah membantu dalam pelaksanaan kegiatan penelitian ini. 


\section{DAFTAR PUSTAKA}

Adjie, N, \& Maulana. 2010. Pemecahan Masalah Matematika. UPI Press.

Bandung.

Anitah W. Sri, ddk. 2009. Strategi Pembelajaran di SD. Jakarta:Universitas Terbuka.

Arsyad, A. 2011. Media Pembelajaran. Jakarta: Rajawali Press.

BSNP. 2006. Standar Isi. Jakarta: BSNP.

Darsono, M. 2010. Belajar dan Pembelajaran. Semarang: IKIP Semarang Press

Doman, G, \& Doman, J. 2005. How To Teach Your Baby Math Bagaimana Mengajar Bayi Anda Matematika Sambil Bermain.Jakarta: TM Press.

Hamalik, O. 2010. Proses Belajar Mengajar. Bandung: Bumi Aksara.

Ismail, A. 2010. Education Games Menjadi Cerdas dan Ceria dengan Permainan Edukatif. Yogyakarta: Pilar Media.

Isnaeni, N. F. 2013. Penggunaan Media Kartu Bilangan untuk Meningkatkan Motivasi dan Hasil Belajar Materi Bilangan Romawi Pada Siswa Kelas IV Sekolah Dasar Negeri Debong Tengah 1 Tegal. https://lib.unnes.ac.id/17341/1/1401409066.p df

Mentari. 2015. Penerapan model active learning tipe card sort untuk meningkatkan aktivitas dan hasil belajar matematika siswa kelas IV SD Negeri 1 Jurang Ubung. http://digilib.unila.ac.id/22290/3/SKRIPSI\%2 OTANPA\%20BAB\%20PEMBAHASAN.pdf

Rifa'i, A \& Anni, C. T. 2010. Psikologi Pendidikan. Semarang: UNNES Press.

Slameto. 2013. Belajar Dan Faktor-Faktor Yang Mempengaruhinya. Jakarta: Rineka Cipta.

Silberman, M. 2013. Active Learning: 101 Strategi Pembelajaran Aktif. Penerjemah: Sarjuli. Yogyakarta: Insan Madani.

Subarinah, S. 2010. Inovasi Pembelajaran Matematika Sekolah Dasar. Depdiknas. Jakarta.

Uno, H, \& Mohamad, N. 2011. Belajar dengan Pendekatan PAIKEM. Jakarta: PT Bumi Aksara.

Uzer, U. M. 2013. Menjadi Guru Profesional. Bandung:PT. Remaja Rosdakarya.

Zaini, H. 2008. Strategi Pembelajran Aktif. Yogyakarta: Pustaka Insan Madani. 